\title{
Evaluation of e-Governance Automated Processes in University Administration
}

\author{
Eleni Symeonaki \\ Dept. of Automation Eng. \\ PUAS \\ Athens, Greece
}

\author{
Michail Papoutsidakis \\ Dept. of Automation Eng. \\ PUAS \\ Athens, Greece
}

\author{
Dimitrios Tseles \\ Dept. of Automation Eng. \\ PUAS \\ Athens, Greece
}

\begin{abstract}
E-Governance enhances the quality of transactions both within the government, as well as between the government and other parties through the delivery of cost-effective and easy-to-access automated processes. As part of a potent higher education system, which is essential for the development of society, automated processes in management and administration of public higher educational institutes is a rapidly evolving field because of its high efficiency and effectiveness. Although there is a comparatively short number of research studies reported in literature, regarding the evaluation of e-Governance implementations in university administration, it has been determined that the integration of automated processes helps to enhance the overall administration of higher education. This paper describes an evaluation study on automated processes implementation in the administration of Piraeus University of Applied Sciences, which is one of the greatest higher educational institution in Greece. The evaluation was performed after the selection of the most appropriate method for this purpose. The outcomes of this study suggest that the university as well as its academic community are highly benefitted by the automated administrative processes and the implementation of the Integrated Information System in terms of educational management, strategy planning, distributing resources as well as organizational success. Consequently, it becomes obvious that enduring participative evaluation actions affect positively the general perception and attitude of the academic community towards automated administrative processes and are essential for the future success of the university.
\end{abstract}

\section{Keywords}

e-Governance; Educational management; Integrated Information System; Automated Administrative Processes; Evaluation.

\section{INTRODUCTION}

The term Government is attributed to the total of specialized public institutions which contribute to governance. Representative governments pursue citizen support and are based on the active cooperation of their public servants. Governance is the outcome of politics applied by a government [1].

The term Electronic Governance (e-Governance) stands for the implementation of Information and Communication Technologies (ICT) in planning, management as well as monitoring of government programs and activities [2].

E-Governance enhances the quality of transactions both within the government, as well as between the government and other parties through the delivery of cost-effective and easy-to-access automated processes. In particular, establishing an ICT environment increases the transparency and accountability of public services and facilitates moral \& material progress for all citizens.

There are several models regarding e-Governance interaction types, which all aim in the reduction of services repeatability and the increase of information and services delivered to citizens [3]. The main interaction types of e-Governance according to Siau \& Long model [4] are the following (Fig. $1)$ :
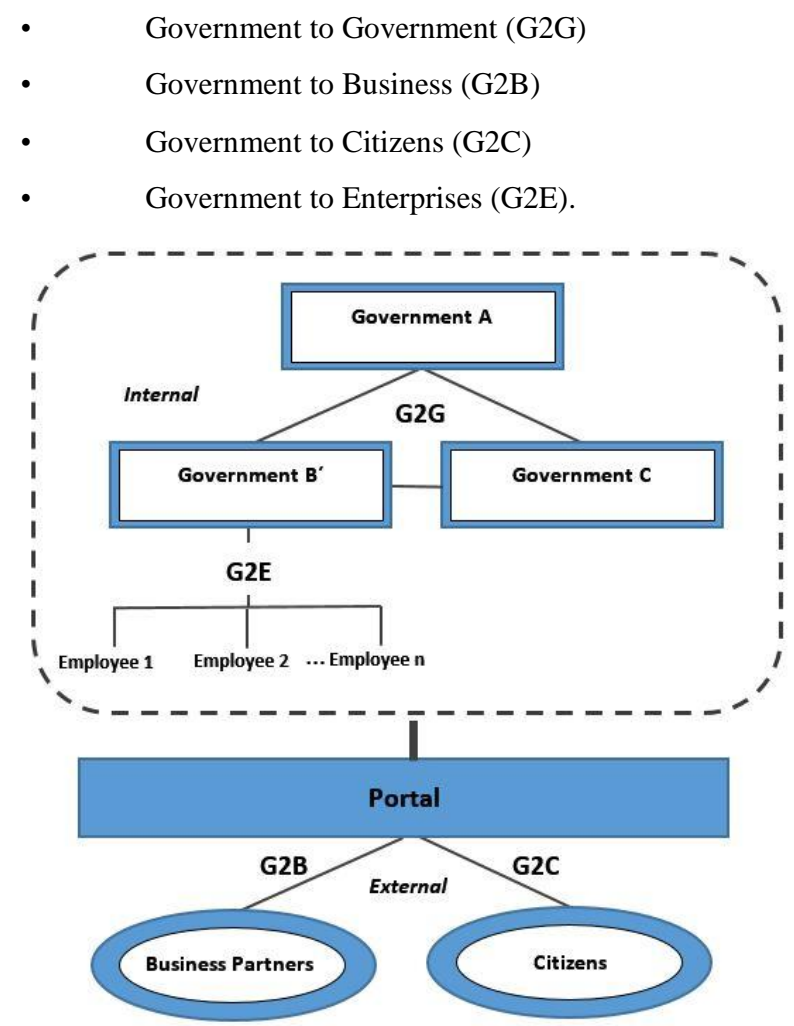

Fig 1: Siau \& Long Model e-Governance Interactions

Through the adoption of e-Governance solutions in every administrative facility of a university, real time information processing and knowledge management of the institution is made possible. The implementation of such e-Governance solutions involves the integration of all data and processes, related to the university, into an Information System. This Integrated Information System combines all the administrative and university management modules which are required for the successful processing and handling of large volumes of data among various departments in the university, concerning processes such as registrations, admissions, student information, classes, time tables, transports, attendance, 
library, salary and expenses, examinations, performance, grades, reports and so on.

Management Information Systems (MIS) as part of eGovernance solutions in educational management and administration is a relatively innovative field which is rapidly evolving because of its high efficiency and effectiveness.

An Education Management Information System (EMIS) helps educational institutions to achieve a mature level of automation by managing their procedures through data collection, processing, analysis and reporting (Fig. 2).

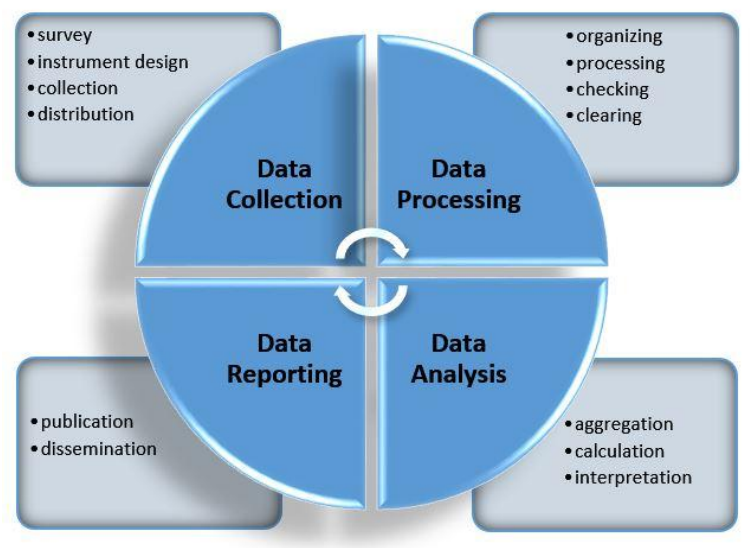

Fig 2: Typical life cycle of EMIS information

EMIS information can be used in research, policy and planning, reviewing and evaluation as well as decision making by creating indicators which continuously monitor the overall performance of an educational organization.

Managing universities procedures and activities requires a University Management Information System (UMIS) which provides the required tools for organizing, evaluating, and efficiently running departments. A UMIS refers broadly to a centralized computer-based system consisting of hardware, software, people, data, and information that can be accessed by all areas of the university as in [5].

A typical UMIS includes the following components (Fig. 3):

Student Information System which is responsible for managing data of university students such as student's ID, name, gender, date of birth, contact information, username, password, faculty, department, university status and so forth as in [6].

- Library Information System which is used for managing and automating university libraries. Automated libraries contain digitized material in database records that reflect the tasks performed by librarians in order to manage them in an effective way as in [7]. A typical database record may include ISBN, title, authors, keywords, and data like section, list of all books, list of available borrowed and books, borrowers' data, return deadlines, and so forth as in [8].

Faculty Information System which manages and automates managerial activities related to instructors, employees, courses and the intersections between them. A typical faculty information system database record may include a) faculty data such as ID, name, departments etc.; b) course information such as course ID, name, description, instructors etc. and c) faculty personnel data such as ID, social security number, name, date of birth, gender, contact information, employment details, username, password and so forth as in [9]

- Finance System which manages financial issues that refer to faculty or university as much as to any organization.

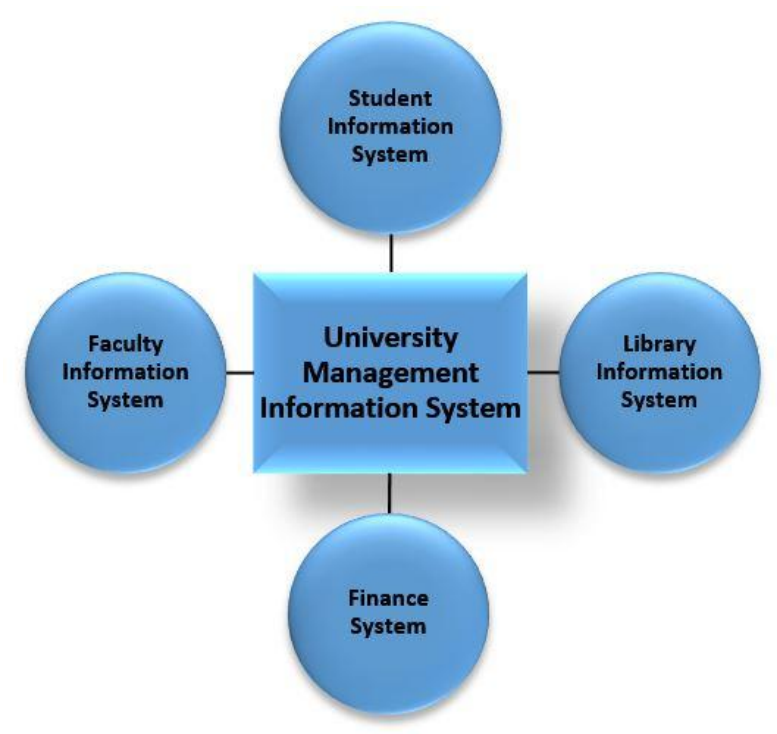

Fig 3: University Management Information System (UMIS)

\section{CONCEPTUAL FRAMEWORK OF UMIS EVALUATION}

Evaluating the impact of a computer-based UMIS requires, besides understanding computer technology, an understanding of the social and behavioral processes that affect and are affected by the introduction of the technology into the practice setting. According to the conceptual framework presented by Ives, Hamilton, and Davis [10] as well as Kraemer and Dutton [11], research and evaluation of information systems may involve any or all of the following categories a) the external environment of the organization, b) the internal environment of the organization, c) the information system users, d) the systems development environment and staff, e) the management and operational environment of the system, f) the nature of the system including the information processed, g) patterns of utilization, h) organizational impacts and i) social impacts.

Two of the fundamental approaches that have been developed for the evaluation of Information Systems are:

1) Technology Acceptance: Davis [12] proposed the Technology Acceptance Model (TAM) to investigate the impact of technology on user behavior (Fig. 4). The model focuses on the process of using technology, where "Perceived Usefulness" and "Perceived Ease of Use" are the two key factors that affect an individual's intention to use a technology. Perceived Usefulness means that the user believes the technology will improve his/ her performance, while Perceived Ease of Use refers to the belief that using the technology will be free of effort. Venkatesh and Davis [13] suggested that Perceived Usefulness and Perceived Ease of Use could be affected by external variables. For example, they found that computer self-efficacy is an important variable and assumed that a positive relationship exists between higher computer self-efficacy on the one hand and Perceived 
Usefulness and Perceived Ease of Use on the other. The studies of Venkatesh [14] confirmed the hypotheses about positive causal relationships posited in previous research.

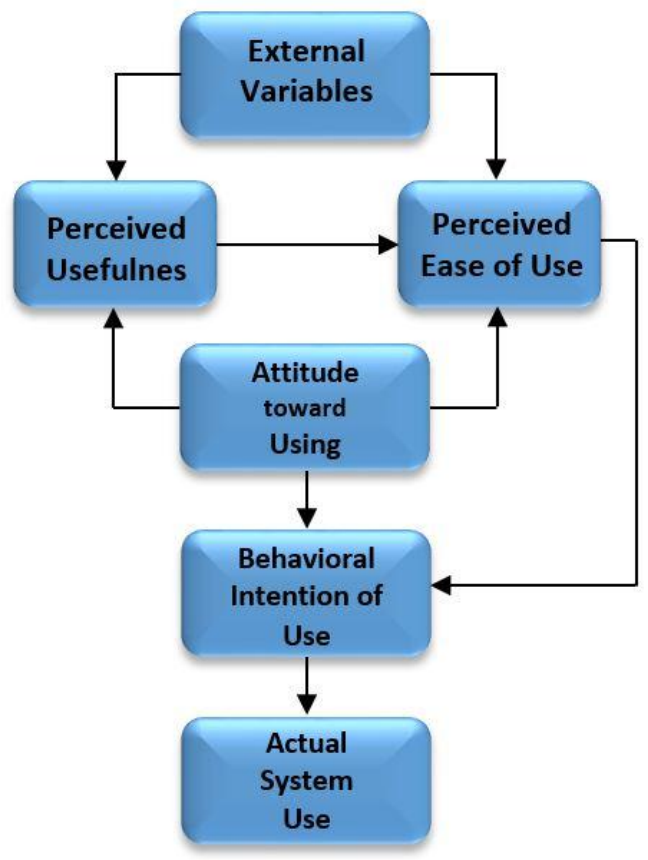

Fig 4: Technology Acceptance Model (TAM)

2) User Satisfaction: To measure the success of Information systems Delone and McLean [15] reviewed the research published during the previous years. Based upon their research they identified six variables of IS successsystem quality, information quality, use, user satisfaction, individual impact and organizational impact.

These are interdependent variables. D\&M model states that the amount of system use can affect the degree of user satisfaction (Fig. 5). No empirical validation of the model was proposed by them.

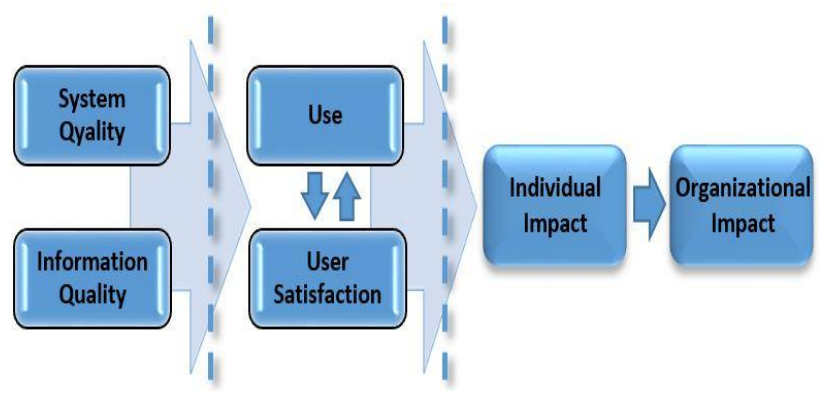

Fig 5: Original D\&M IS Success Model

\section{THE PUAS INFORMATION SYSTEM}

Piraeus University of Applied Sciences (PUAS) is an independent and self- governed Institute of public higher education and its operation is based on the Greek state laws. The degrees offered are recognized by the Greek state and EU and are fully evaluated. In Piraeus University of Applied Sciences exist nine (9) Academic Departments, grouped in two Schools. There are approximately 35 Laboratories in both Schools that support the teaching as well as research and development activities. The Laboratories are engaged in several research and development programs that are funded by the Greek Government and European Union. The studies in the Departments of PUAS for the first level degrees are of four year typical duration and equivalent to 240 ECTS, according to the Bologna Process Guidelines. After graduation, studies in the second level are offered through MSc programs that last one to two years and weight 90-120 ECTS. Then, a third level course is possible for $\mathrm{PhD}$ studies in collaboration with several Universities in Greece or in European region. The campus is located near the center of Athens and the port of Piraeus and extends on an area of about $100.000 \mathrm{~m} 2$, including several buildings with the equivalent of $50.000 \mathrm{~m} 2$ space. Among them the Conference Center and the library are encountered. There are facilities that cover all students' needs and support academic activities. Each year approximately $1.500-2.000$ new students are enrolled in Piraeus University of Applied Sciences and the total number of the active students is approximately 12.000 . The permanent Academic Staff is encountered to 160 Professors. The teaching staff is enriched with approximately 300 part time professors. The academic operation is supported by 160 permanent members of the administration staff. These operations are also supported by approximately 30 additional persons that are engaged in several $R \& D$ programs.

Piraeus University of Applied Sciences (PUAS) received at the end of 2015 and initiated the upgrade of the Information System and new hardware (servers and Wireless Communication Systems). The purpose of upgrading the Information System was to provide personalized web services to students, professors and academic staff through an electronic Portal type point (Fig. 6).

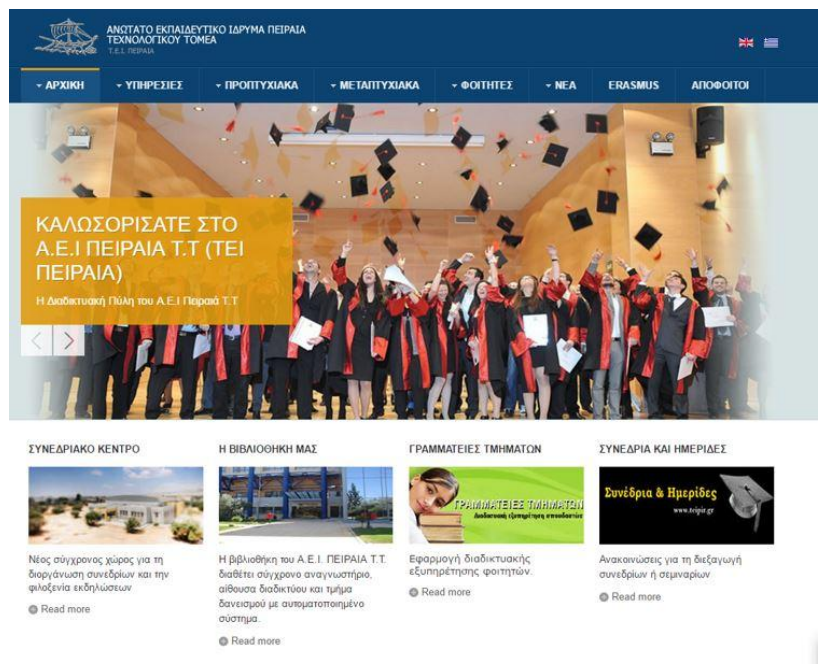

Fig 6: PUAS Electronic Portal

Interventions were implemented in the following modules:

- Students Records - Secretariats Management

- $\quad$ Student Club

- $\quad$ Personnel Management

- $\quad$ Financial Management and Asset Management

- $\quad$ Procurement Management

- Electronic Protocol and Workflow Management 


\section{- Information subsystem for assisting the work} Quality Assurance Unit of PUAS

The Integrated Interactive Digital Technology System (ODSPST) expands the existing e-Government services of PUAS, providing a modern and efficient interface unit (single point of contact) for all members of the academic community (professors, administrative staff and students) of the Institute. One-stop online services have been implemented and are available to members of the academic community (such as students and instructors), the personnel and external parties (such as citizens, suppliers and traders) in order to transact in a user-friendly way with the secretariats and administrative departments of PUAS (Fig. 7).

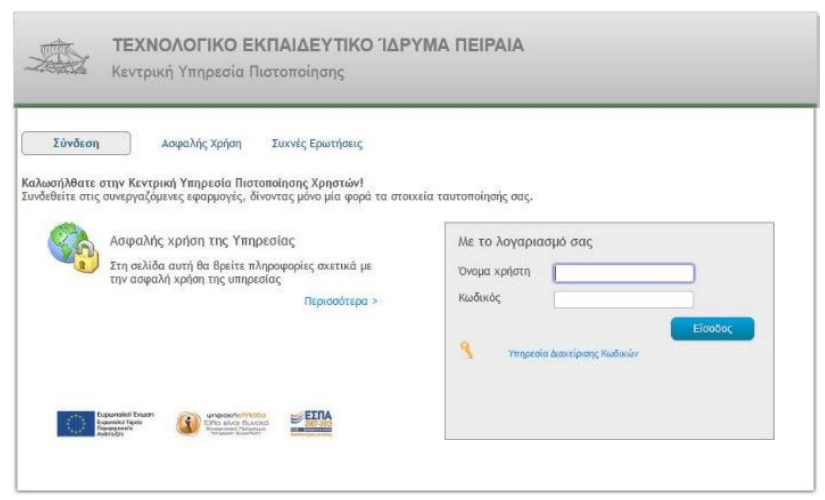

Fig 7: PUAS single point of contact interface

The system is interconnected with the Central Information of GUNet system, according to the requirements provided centrally for all national universities, ensuring the immediacy of communication and interoperability. Regarding the enduser interface, web interfaces (www) are supported both for PC (desktop or laptop) as well as for smartphone or tablet. Furthermore, the notification of those concerned regarding the progress of their electronically submitted requests is performed by text messaging (SMS service) and by email. Apart from the web applications which cover the entire range of transactions with PUAS, important modules of the system are a) the workflow automation provided by the usage of the interconnected "Electronic Protocol and Workflow Management System" (Fig. 8) as well as the implementation of digital signature, and b) the operation Wi-Fi in PUAS campus.

The Integrated Interactive Digital Technology System (ODSPST) aims to benefit Piraeus University of Applied Sciences in terms of e-Governance by:

- Immediately improving PUAS provided services to citizens and increasing staff productivity.

- $\quad$ Contributing to a better exploitation of hither to on investment in PUAS.

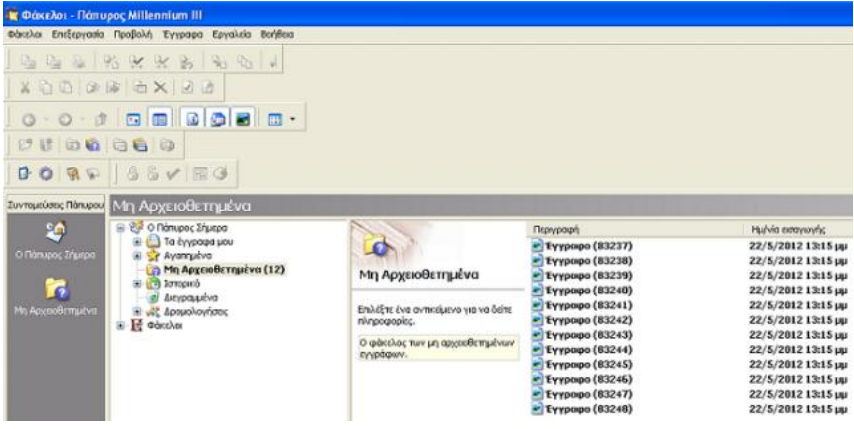

Fig 8: PUAS Electronic Protocol and Workflow Management System

- $\quad$ Successfully transforming PUAS in e-University both technically and organizationally

- Contributing to the gradual technical and organizational adaptation of PUAS in the new environment

- $\quad$ Enabling internal development of new applications and adaption of the existing ones, by using an intermediate technological background and raw data to provide statistical data/reports and feeding decision support systems.

- $\quad$ Enabling interconnection of university applications horizontal central applications YPDVMTH within the overall strategy of YPDVMTH.

- $\quad$ Reducing staff workload of the secretariats and administrations and overcrowding observed in transactions.

- Improving the service of students and minimizing contact of the student with the Secretariat of the Department where it belongs (Fig. 9).

- Improving the administrative operation of PUAS in both qualitative and productive level and releasing a critical mass of personnel that can support the development institution.

- Improving service operators and collaboration with PUAS (Trade Ministry, NSS, etc.).

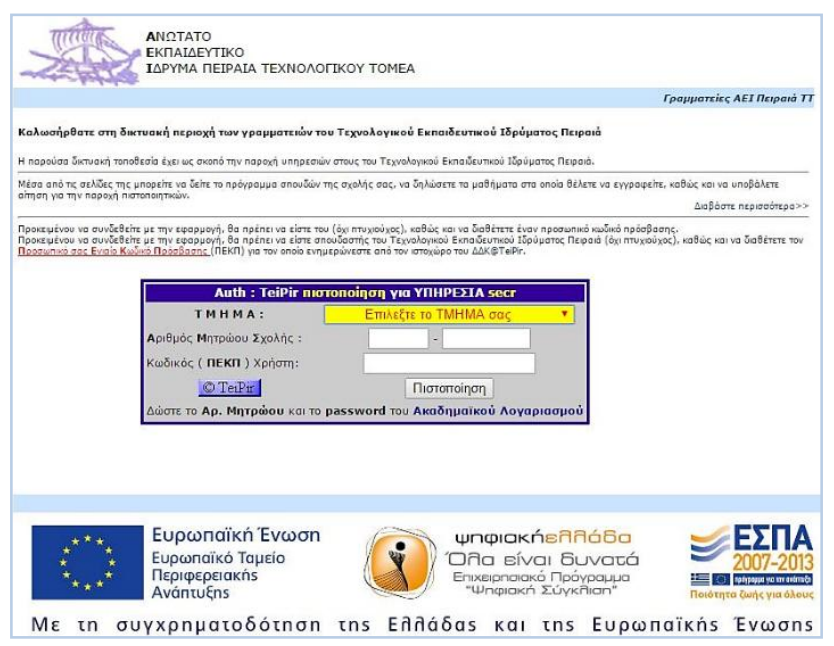

Fig 9: PUAS web secretariat interface 


\section{EVALUATION OF PUAS STUDENT INFORMATION SYSTEM}

\subsection{Methodology}

On the first stages of our research concerning the evaluation of PUAS Information System the survey was focused on the Student Information System (SIS).

In order to perform the evaluation, the research model, offered by Wixom and Todd [16] is selected to be applied. This model incorporates both TAM and IS success in theoretical and conceptual framework and contains three parts:

- TAM model: 3 basic parameters and 1 external parameter)

- $\quad$ IS SUCCESS model: 3 parameters

- External factor: demographics elements

The research objectives are:

- $\quad$ User satisfaction

- Technology acceptance

- Connection between user satisfaction and technology acceptance.

The Hypothesis of the research model is shown in "Tab. 1".

Table 1. Hypothesis of the Research Model

\begin{tabular}{|c|c|c|}
\hline $\mathbf{H}$ & 0 & 1 \\
\hline 1 & $\begin{array}{l}\text { Overall satisfaction } \\
\text { is not influenced } \\
\text { by information quality }\end{array}$ & $\begin{array}{l}\text { Overall satisfaction is } \\
\text { influenced by } \\
\text { information quality }\end{array}$ \\
\hline 2 & $\begin{array}{l}\text { Overall satisfaction } \\
\text { is not influenced by } \\
\text { information system }\end{array}$ & $\begin{array}{l}\text { Overall satisfaction is } \\
\text { influenced by } \\
\text { information system }\end{array}$ \\
\hline 3 & $\begin{array}{l}\text { The intended use of IS } \\
\text { is not affected by the } \\
\text { perceived usefulness }\end{array}$ & $\begin{array}{l}\text { The intended use of IS } \\
\text { is affected by the } \\
\text { perceived usefulness }\end{array}$ \\
\hline 4 & $\begin{array}{l}\text { The intended use of IS } \\
\text { is not affected by } \\
\text { the perceived Ease of } \\
\text { Use }\end{array}$ & $\begin{array}{l}\text { The intended use of IS } \\
\text { is affected by the } \\
\text { perceived Ease of Use }\end{array}$ \\
\hline 5 & $\begin{array}{l}\text { The intended use of IS } \\
\text { is not affected } \\
\text { by the Experience }\end{array}$ & $\begin{array}{l}\text { The intended use of IS } \\
\text { is affected by the } \\
\text { Experience }\end{array}$ \\
\hline 6 & $\begin{array}{l}\text { The intended use of IS } \\
\text { is not affected by the } \\
\text { overall satisfaction }\end{array}$ & $\begin{array}{l}\text { The intended use of IS } \\
\text { is affected by the } \\
\text { overall satisfaction }\end{array}$ \\
\hline 7 & $\begin{array}{l}\text { The overall satisfaction } \\
\text { is not affected by } \\
\text { demographic elements }\end{array}$ & $\begin{array}{l}\text { The overall satisfaction } \\
\text { is affected by } \\
\text { demographic elements }\end{array}$ \\
\hline 8 & $\begin{array}{l}\text { The intended use of IS } \\
\text { is not affected by } \\
\text { demographic elements }\end{array}$ & $\begin{array}{l}\text { The intended use of IS } \\
\text { is affected by } \\
\text { demographic elements }\end{array}$ \\
\hline
\end{tabular}

\subsection{Data Collection}

In PUAS exist 9 departments grouped in two schools: Engineering and Business \& Economics. The data was collected through a questionnaire (Fig. 10) which was addressed to a small sample of users. The sample included students of all PUAS departments and the survey was performed during the spring semester of Academic Year 2015-2016. In total 109 students of various typical semesters and PUAS departments (of both faculties) responded to the questionnaires (Tab. 2).

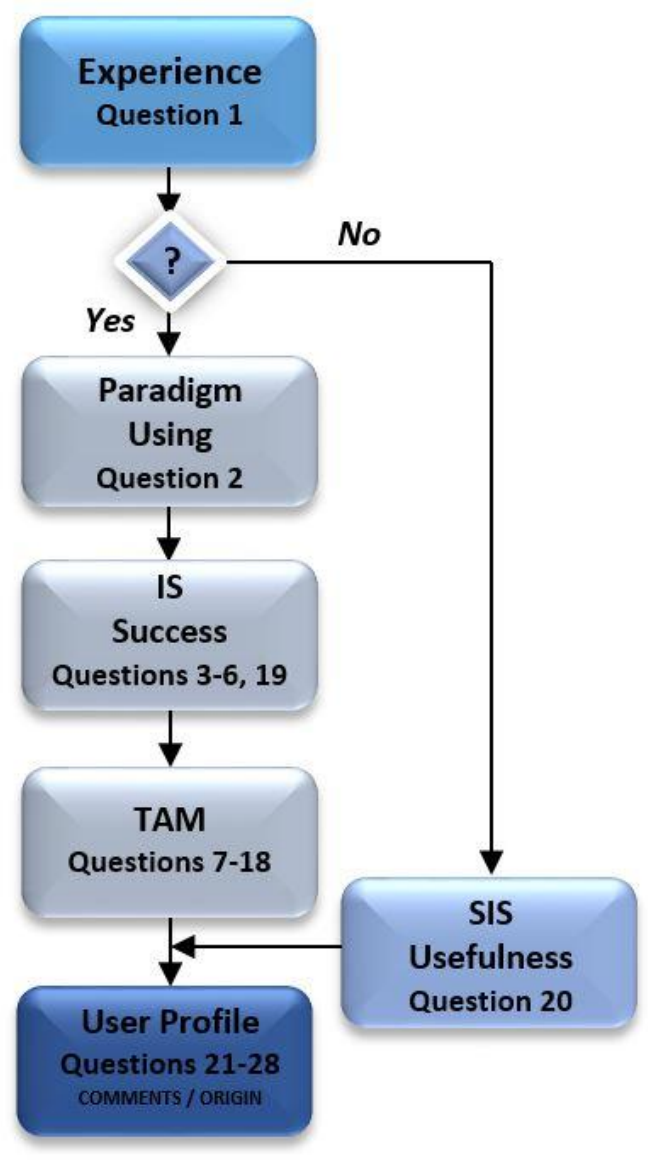

Fig 10: Questionnaire structure

Table 2. Sample Departments

\begin{tabular}{|c|c|c|}
\hline Department & Frequency & Percent \\
\hline Automation Engineering & 19 & 17.1 \\
\hline Civil Engineering & 7 & 6.3 \\
\hline Electrical Engineering & 23 & 21.2 \\
\hline Electronic Engineering & 12 & 11.4 \\
\hline Mechanical Engineering & 13 & 12.0 \\
\hline Textile Engineering & 4 & 4.0 \\
\hline Accounting and Finance & 21 & 19.0 \\
\hline Business and Administration & 10 & 9.0 \\
\hline Total & 109 & 100.0 \\
\hline
\end{tabular}

\subsection{Data Processing}

This research uses some methods and techniques based in Descriptive \& Inferential statistics. The data processing was performed using SPSS software (version 20) and Microsoft Excel 2013. The data processing framework is presented in "Fig. 11". 


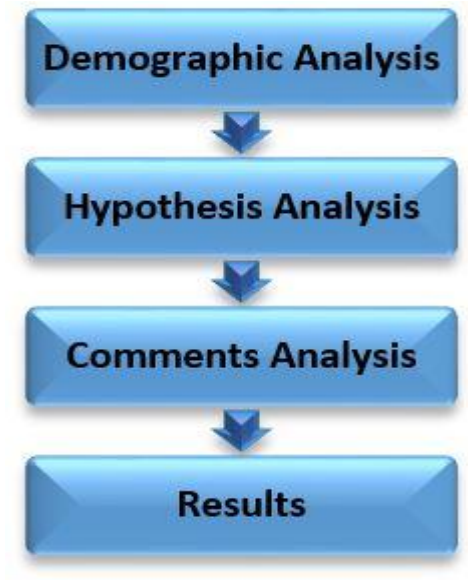

Fig 11: Data processing framework

\subsection{Reliability and Validation}

For the purposes of this research Cronbach Alpha technique is used regarding reliability analysis (Tab. 3) and face validation regarding validation analysis (Tab. 4 ).

Table 3. Reliability analysis

\begin{tabular}{|c|c|c|c|}
\hline Models & Variables & $\begin{array}{c}\text { Cronbach } \\
\text { Alpha }\end{array}$ & Comments \\
\hline \multirow{2}{*}{$\begin{array}{c}\text { IS } \\
\text { Success }\end{array}$} & $\begin{array}{c}\text { Information } \\
\text { quality }\end{array}$ & 0.886 & High reliability \\
\cline { 2 - 4 } & $\begin{array}{c}\text { System } \\
\text { quality }\end{array}$ & 0.792 & $\begin{array}{c}\text { Satisfactory } \\
\text { reliability }\end{array}$ \\
\hline \multirow{3}{*}{ TAM } & Usefulness & 0.657 & $\begin{array}{c}\text { Simple } \\
\text { reliability }\end{array}$ \\
\cline { 2 - 4 } & Ease of use & 0.845 & High reliability \\
\cline { 2 - 4 } & Intended use & 0.650 & $\begin{array}{c}\text { Simple } \\
\text { reliability }\end{array}$ \\
\cline { 2 - 4 } & Experience & 0.847 & High reliability \\
\hline
\end{tabular}

Table 4. Validation analysis

\begin{tabular}{|c|c|c|}
\hline Variables & Results (\%) & Comments \\
\hline Structure & 100 & High satisfaction \\
\hline Contents & 70 & $\begin{array}{c}\text { Important } \\
\text { satisfaction }\end{array}$ \\
\hline Research object & 80 & $\begin{array}{c}\text { Important } \\
\text { satisfaction }\end{array}$ \\
\hline Overall satisfaction & 90 & High satisfaction \\
\hline
\end{tabular}

\subsection{Demographic Analysis}

The results which derived regarding the demographic analysis are the following:

The majority of the sample $(92.4 \%)$ has used the PUAS Student Information System and from them, the majority (89\%) has used it for more than two types of transactions (such as semester enrollment and certificate applications).

- The majority of the sample is males $(58.8 \%)$.

- The majority of the sample belongs to the middle income level ( 46\%).

- $\quad$ The majority of the sample is unemployed (51.7\%).
- The majority of the sample belongs to the age group 18-25 (65.2\%).Section 3 and subsection 3.1), use no additional space above the subsection head.

\subsection{Hypothesis Analysis}

For the purposes of the Hypothesis Analysis a KolmogorovSmirnov (K-S) \& Shapiro-Wilk (S-W) test and Kruskall Wallis, Mann-Whitney were performed.

- Using Kolmogorov-Smirnov (K-S) \& Shapiro-Wilk (S-W) test (research variables): there is no normal distribution of the samples ( $\mathrm{Sig}<0.05$ ).

- Using non-parametric tests (Kruskall Wallis, MannWhitney): the samples are not normally distributed.

The results of Hypothesis analysis are presented in "Tab.5":

Table 5. Hypothesis analysis

\begin{tabular}{|c|c|c|c|}
\hline $\begin{array}{c}\text { Research } \\
\text { objectives }\end{array}$ & $\begin{array}{c}\text { Questionnaire } \\
\text { Questions }\end{array}$ & Hypothesis & $\begin{array}{c}\text { Results } \\
\text { (after } \\
\text { checking) }\end{array}$ \\
\hline $\begin{array}{c}1 . \\
\text { User } \\
\text { satisfaction }\end{array}$ & $3,4-19$ & $\mathrm{H} 1.0-\mathrm{H} 1.1$ & $\mathrm{H} 1.1$ \\
\cline { 2 - 4 } & $5,6-19$ & $\mathrm{H} 2.0-\mathrm{H} 2.1$ & $\mathrm{H} 2.1$ \\
\hline $\begin{array}{c}\text { Technology } \\
\text { acceptance }\end{array}$ & $7 \ldots 9-15,16$ & $\mathrm{H} 3.0-\mathrm{H} 3.1$ & $\mathrm{H} 3.1$ \\
\cline { 2 - 4 } & $10 \ldots 14-15,16$ & $\mathrm{H} 4.0-\mathrm{H} 4.1$ & $\mathrm{H} 4.1$ \\
\hline \multirow{2}{*}{$\begin{array}{c}\text { User } \\
\text { satisfaction }\end{array}$} & $19-21,22,23$ & $\mathrm{H} 7.0-\mathrm{H} 7.1$ & $\begin{array}{c}\mathrm{H} 7.1 . \mathrm{H} \\
\text { H7.b. }\end{array}$ \\
\cline { 2 - 4 } $\begin{array}{c}\text { Technology } \\
\text { acceptance }\end{array}$ & $15,16-21,22$, & $\mathrm{H} 5.0-\mathrm{H} 5.1$ & $\mathrm{H} .50$ \\
\cline { 2 - 4 } & 23 & $\mathrm{H} 8.0-\mathrm{H} 8.1$ & $\begin{array}{c}\text { H8.0.a } \\
\text { H8.0.b } \\
\text { H8.0.c }\end{array}$ \\
\hline
\end{tabular}

\subsection{Comments Analysis}

The analysis of question 27 in the questionnaire regarding the comments of the sample as far it concerns the PUAS Student Information Systems produced that the answers which appeared the most were:

- Increase the number of transactions offered by the SIS.

- Offer higher ease of use.

- Offer more reliable providing information.

\subsection{Results}

During the study five (5) SIS-modules were identified which included a) student records b) student assessment, c) student registrations d) certificate applications and e) library records. Table 6 illustrates percentages of respondents reporting whether the modules included in PUAS SIS are used by them or not. The results indicate that the most common used modules on the SIS are student registration, student assessment and student records. The least used modules are certificate application and library records.

Results on frequency of SIS module usage, as demonstrated in Table 7 , indicate that $32 \%$ of the respondents use "Library Records" a few times a year. "Student Records" and "Student Assessment" are the most commonly used module every month with $31 \%$ respondents. The "Student Registration" module is the most used a few times a year by $71 \%$, as it is required for the enrollment renewal of the students. Finally 
the "Certificate Application" module is the least frequently used with $34 \%$ of respondents noting that they never used it at all.

Table 6. Modules included in PUAS Student Information System

\begin{tabular}{|c|c|c|}
\hline Student Information System Modules & Yes\% & No \% \\
\hline $\begin{array}{c}\text { Student Records } \\
\text { (personal data) }\end{array}$ & $83 \%$ & $17 \%$ \\
\hline $\begin{array}{c}\text { Student Assessment } \\
\text { (evaluation grades) }\end{array}$ & $90 \%$ & $10 \%$ \\
\hline Student Registration & $91 \%$ & $9 \%$ \\
\hline Certificate Application & $59 \%$ & $41 \%$ \\
\hline Library Records & $67 \%$ & $33 \%$ \\
\hline
\end{tabular}

Table 7. Usage frequency of Modules included in PUAS Student Information System

\begin{tabular}{|c|c|c|c|c|c|}
\hline $\begin{array}{c}\text { Student } \\
\text { Information } \\
\text { System } \\
\text { Modules }\end{array}$ & Never & $\begin{array}{c}\text { Every } \\
\text { Week }\end{array}$ & $\begin{array}{c}\text { Every } \\
\text { Month }\end{array}$ & $\begin{array}{c}\text { Few } \\
\text { Times } \\
\mathbf{a} \\
\text { Year }\end{array}$ & $\begin{array}{c}\text { Once } \\
\mathbf{a} \\
\text { Year }\end{array}$ \\
\hline $\begin{array}{c}\text { Student } \\
\text { Records } \\
\text { personal } \\
\text { data) }\end{array}$ & $12 \%$ & $27 \%$ & $31 \%$ & $19 \%$ & $11 \%$ \\
\hline $\begin{array}{c}\text { Student } \\
\text { Assessment } \\
\text { (evaluation } \\
\text { grades) }\end{array}$ & $12 \%$ & $15 \%$ & $31 \%$ & $30 \%$ & $12 \%$ \\
\hline $\begin{array}{c}\text { Student } \\
\text { Registration }\end{array}$ & $11 \%$ & - & - & $71 \%$ & $18 \%$ \\
\hline $\begin{array}{c}\text { Certificate } \\
\text { Application }\end{array}$ & $34 \%$ & $10 \%$ & $17 \%$ & $28 \%$ & $11 \%$ \\
\hline $\begin{array}{c}\text { Library } \\
\text { Records }\end{array}$ & $25 \%$ & $13 \%$ & $24 \%$ & $32 \%$ & $6 \%$ \\
\hline
\end{tabular}

Table 8 shows the percentage of users using the PUAS Student Information System in hours per month. Of the 100\% of respondents in the sample, $60 \%$ indicated that they both directly and indirectly used SIS with a variation in the usage time. The questionnaire defined former the online use as using the system directly and the use of information (secretariat printouts) as using it indirectly. The data demonstrated in Table VIII below indicates that the time investment for the direct use of the SIS is the highest one, ranging between 1-10 hours per month which implies less time in indirect use. On the other hand, the levels of indirect use are significantly higher between 11-30 hours per month. This seems to be an illogical result for but it is offset by the fact that the respondents are mainly students of the Engineering School, implying that they are more skilled in using the SIS. This indicates that perhaps a lot of students rarely use all of the SIS modules available, but frequently depend on the printouts provided by the secretariats.

On the aspect regarding whether the system provides the required information $11 \%$ replied that it poorly does, $51 \%$ up to some degree, $22 \%$ much and finally $16 \%$ said it very much provides this. About $85 \%$ of the respondents expressed the opinion that all the modules of the SIS always operate properly. Of the remaining $15 \%, 62 \%$ faced one to three problems in modules per month while $38 \%$ face between four and seven problems.
Table 8. Percentage of direct and indirect users of PUAS Student Information System

\begin{tabular}{|c|c|c|}
\hline & Direct use & Indirect use \\
\hline 0 hour & $4 \%$ & $4 \%$ \\
\hline$<1$ hour & $6 \%$ & \\
\hline $1-4$ hours & $34 \%$ & $11 \%$ \\
\hline $5-10$ hours & $26 \%$ & $19 \%$ \\
\hline $11-20$ hours & $8 \%$ & $19 \%$ \\
\hline $21-30$ hours & $10 \%$ & $29 \%$ \\
\hline$>30$ hours & $12 \%$ & $16 \%$ \\
\hline
\end{tabular}

Users have the following opinions (Table IX) on several aspects regarding the perceived quality of the data retrieved from the SIS. An amount of $76 \%$ of the respondents consider the accuracy of information to be very good and so do the respondents between $51 \%$ to $74 \%$ on other aspects such as upto-date information, completeness of information, management support capacity, on-screen retrieval speed and print out speed. Users ranging between 9-33\% are neutral on all the attributes of the SIS data quality, however according to $5-25 \%$ the retrieved SIS information seems to be very poor.

Table 10. Perceived quality of PUAS Student Information System

\begin{tabular}{|c|c|c|c|}
\hline & $\begin{array}{c}\text { Very } \\
\text { Poor }\end{array}$ & Neutral & $\begin{array}{c}\text { Very } \\
\text { Good }\end{array}$ \\
\hline Accuracy of information & $8 \%$ & $16 \%$ & $76 \%$ \\
\hline Up-to-date information & $13 \%$ & $26 \%$ & $61 \%$ \\
\hline $\begin{array}{c}\text { Completeness of } \\
\text { information }\end{array}$ & $21 \%$ & $28 \%$ & $51 \%$ \\
\hline $\begin{array}{c}\text { Management support } \\
\text { capacity }\end{array}$ & $11 \%$ & $33 \%$ & $56 \%$ \\
\hline On-screen retrieval speed & $23 \%$ & $9 \%$ & $68 \%$ \\
\hline Print out speed & $5 \%$ & $21 \%$ & $74 \%$ \\
\hline
\end{tabular}

The overall research results indicate that:

- The overall satisfaction is influenced by the system $\&$ information quality.

- The intended use of the Student Information System is affected by the perceived usefulness and ease of use (Fig. 12).

- The experience does not affect the intended use of Student Information System (Fig. 13).

- Between user satisfaction and intended use small effect appeared.

- $\quad$ The gender affected the overall satisfaction (Fig. 14)

- The overall satisfaction is high for all users of the Student Information System (Fig. 15). 


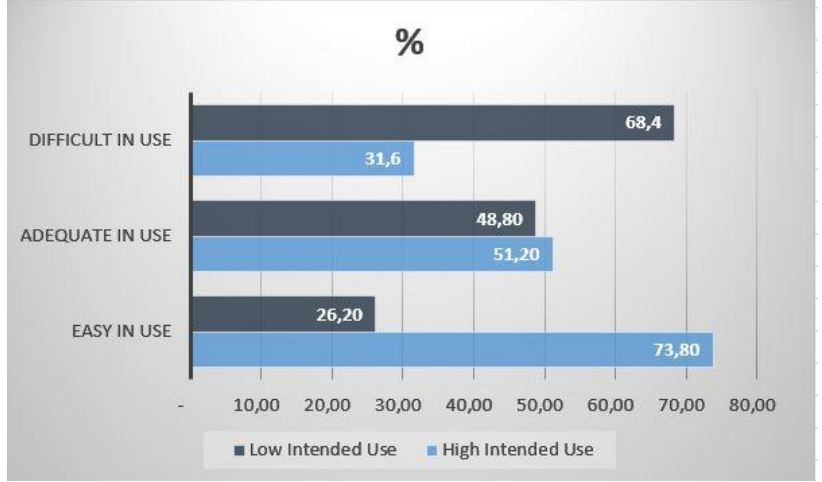

Fig 12: Correlation of the SIS intended use and its perceived usefulness

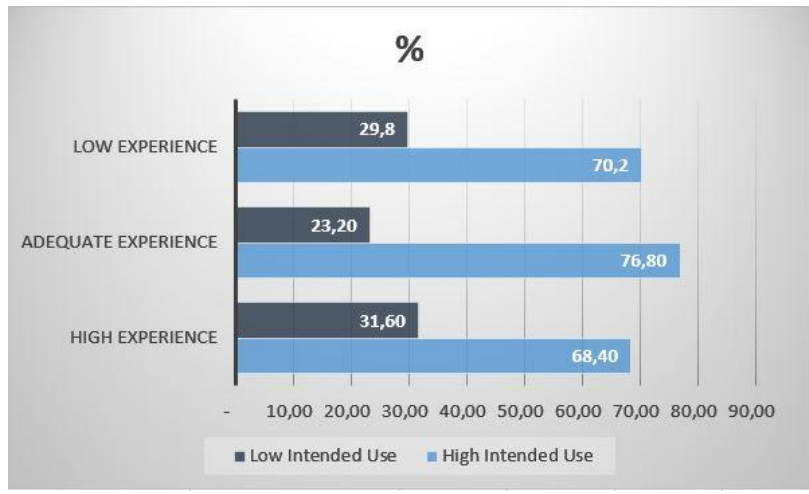

Fig 13: Correlation of user experience and the SIS intended use

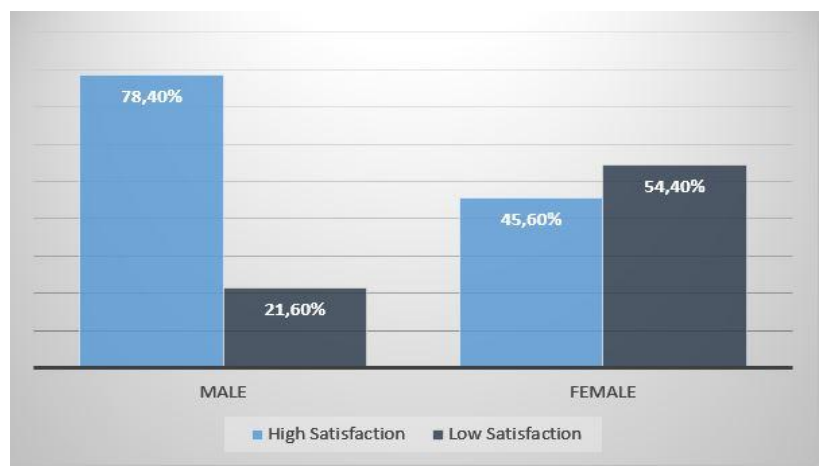

Fig 14: Correlation of users' gender and the SIS overall satisfaction

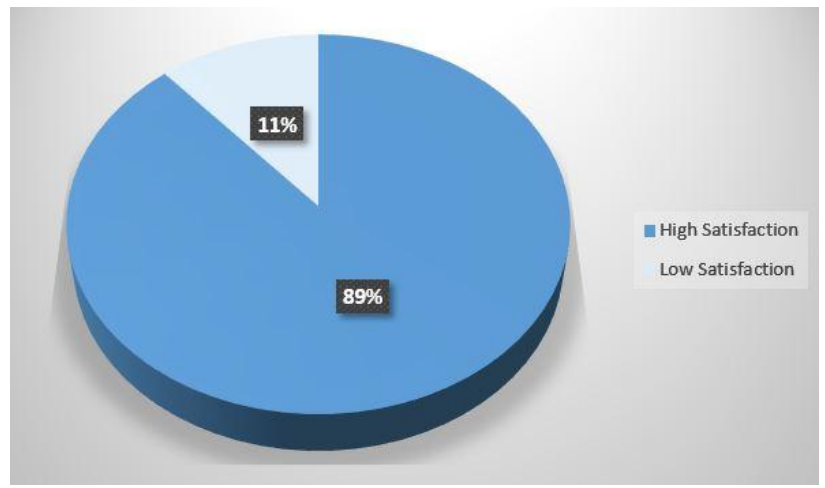

Fig 15: Overall user satisfaction distribution

\section{RESULTS - FURTHER RESEARCH}

The outcomes of this research suggest that PUAS and its academic community could be greatly benefitted by the implementation of the Student Information System in terms of strategy planning, distributing resources as well as organizational success.

In particular, the results indicate that the Student Information System besides improving the provided services to students and minimizing their contact with the Secretariats of their Departments, also contributes both technically and organizationally to the successful transformation of PUAS in e-University. Moreover, positive feedback from student users indicates that improvement actions enhance the confidence in PUAS Student Information System.

Consequently, as the overall satisfaction is influenced by the system and information it became clear that constant participative evaluation initiatives, integrated into the project management process are essential for the future success of PUAS Student Information System.

Taking into consideration that PUAS Integrated Interactive Digital Technology System is fully functional the research group is extending the evaluation research to the total of its applications in order to provide a useful framework for the planning and implementation of an effective constant evaluation of the University Information System leading to its further development and improvement.

\section{ACKNOWLEDGMENTS}

All authors would like to express their gratitude to the Piraeus University of Applied Sciences for providing the required data and funding in order to undertake and complete this research project as part of "Industrial Automation" Postgraduate Program of Studies.

\section{REFERENCES}

[1] Kettl, D., "The transformation of governance", John Hopkins University Press, Baltimore and London, 2002

[2] Godse V \& Garg A, "From E-government to EGovernance, 5th International Conference on egovernance, Hyderabad, India (28-30 December, 2007).

[3] Seifert, JW \& Petersen, RE 2002, "The Promise of All Thing E: Expectations and Challenges of Emergent Electronic Government", Perspectives on Global Development and Technology, vol. 1, issue 2, pp. 193212

[4] Siau, K \& Long, Y, "Synthesizing e-governement stage models - a metasynthesis base on meta-ethnography approach", Industrial Management \& Data Systems, vol 105, no4, pp 443-458, 2005.

[5] Madiha Shan, "Impact of Management Information Systems (MIS) on school administration: What the literature says", 5th World Conference on Educational Sciences - WCES 2013.

[6] Haitham A. El-Ghareeb, "E-Learning and Management Information Systems: Universities Need Both", eLearn Magazine (September 2009)

[7] Long, L. E. and Long N. "Introduction to Computers and Information Systems: The Internet Edition", Prentice Hall, 1996

[8] Riad, A.M. and El-Ghareeb, H. A. "A Service Oriented Architecture to Integrate Web services and Software Agents in Course Management Systems", Egyptian 
Informatic Journal, Cairo University, 2007, Vol. 8, Issue 1.

[9] Madan Mohan Kashyap, "Classified Catalogue Code of Ranganathan: A Proposal to Make it Compatible for Developing Computer-Based Library Information Systems", DESIDOC Bulletin of Information Technology, Vol. 21, No. 1, January 2001, pp. 3-19

[10] Wendi Arant, Leila Payne, (2001) "The common user interface in academic libraries: myth or reality?", Library Hi Tech, Vol. 19 Iss: 1, pp.63 - 76

[11] B. Ives, S. Hamilton, and G.B. Davis.A framework for research in computer-based management information systems, Management Science 26 (1980) 910-934.

[12] K.L.Kraemer and W.H.Dutton.Survey research in the study of management information systems, in: K.L. Kraemer, editor, The Information Systems Research Challenge: Survey Research Methods, Vol. 3 (Harvard Business School, Boston, MA, 1991), pp. 3-57.

[13] Davis, F. Perceived usefulness, perceived ease of use, and user acceptance of information technology. MIS Quart. 13(3), 1989, pp. 319339.

[14] Venkatesh, V., \& Davis, F. D. A model of the antecedents of perceived ease of use: Development and test. Decision Sciences, 27, 1996, pp.451-481.
[15] Venkatesh, V. Determinants of perceived ease of use: Integrating control, intrinsic motivation, and emotion into the technology acceptance model. Information Systems Research, 11(4), 2001, pp. 342-365.

[16] DeLone, W. H., McLean, E. R. Information systems success: The quest for the dependent variable. Information Systems Research, 3(1), 1992, pp. 60-95.

[17] Wixom B.H., P. A. Todd, A Theoretical Integration of User Satisfaction and Technology Acceptance, Information systems research, Vol. 16 (1), 2005, pp. 85102.

[18] Cicmil, S. (1999), "An insight into management of organizational change projects", Journal of Workplace Learning, Vol 11, No.1, pp 5-15, MCB University Press.

[19] Kebede, G. (2002) "The changing information needs of users in electronic information environments", The Electronic Library, Vol 20, No.1, pp1421, MCB University Press.

[20] Glaser, G. \& Strauss, L. (1967) The Discovery of Grounded Theory: Strategies for Qualitative Research, Aldine de Gruyter, New York..

[21] Spector, A. Z. 1989. Achieving application requirements. In Distributed Systems, S. Mullender 